\title{
CONCHA ESPINA'NIN RETAGUARDIA ROMANINDA SİYASET VE KADIN
}

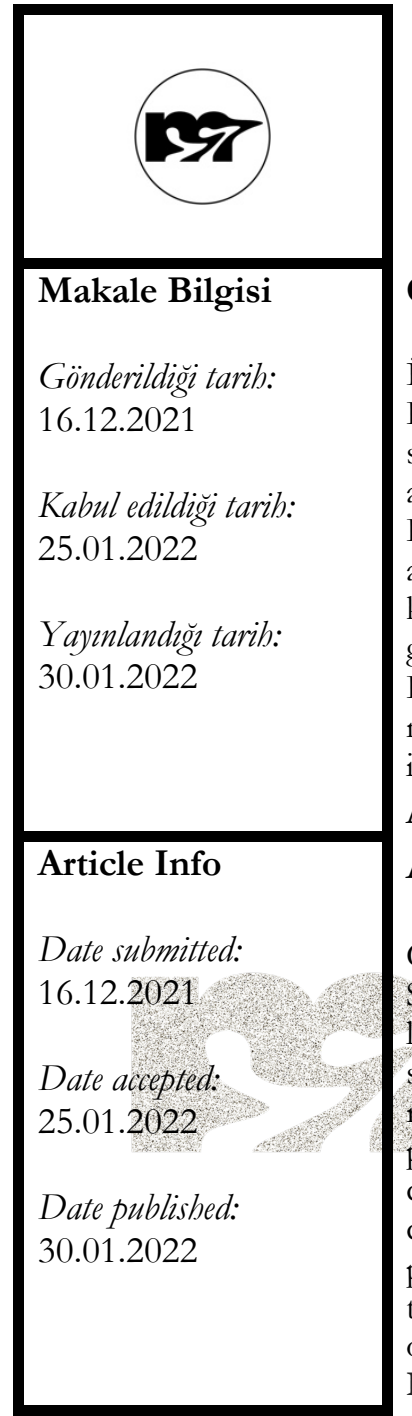

Zeynep ÇELÍKEL ${ }^{1}$

Öz

İspanyol İç Savaşı ve savaş sonrası dönemin önde gelen kadın yazarlarından Concha Espina gerek öz yaşamında gerek yapıtlarında siyasete yakın durmuş, kadın haklarını savunurken aynı zamanda diktatör Franco'yu da destekleyen aydınlar arasında yer almıştır. Farklı dönemlerde İspanyol hükümetinin resmi temsilciliğini yapmış, Nobel Edebiyat Ödülü’ne aday gösterilmiştir. Ülkede Cumhuriyetin ilanından İç Savaş’a ve ardından yaşanan Franco dönemine uzanan siyasi ve toplumsal değişimler ile bunların kadın hakları alanına etkisi, Espina'nın bilhassa romanlarında, muhafazakâr-ulusalcı görüşleri ve İç Savaş deneyimi temelinde yansıma bulmuştur. Bu çalışmanın amacı, Espina'nın Retaguardia adlı romanında İspanyol İç Savaşı'ndan hareketle otobiyografik nitelikli siyasi unsurları ve kadın izleğini yazara dönük biyografik eleştiri yoluyla incelemektir.

Anahtar Kelimeler: Espina, Retaguardia, kadin, iç savass, Franco, İspanyol Edebiyatı.

Abstract

Concha Espina, one of the most prominent women writers lived and wrote during the Spanish Civil War and post-war era, had close ties with politics both in her life and literature, also being among the intellectuals who defended women's rights while supporting the Spanish dictator Franco. Espina officially represented her country during rule of different governments, and was nominated for Nobel Prize in Literature. The political and social changes emerged with the proclamation of the Republic and continued throughout the Civil War and subsequently during Franco era. These changes, having impact on women's rights, were reflected as conservative-nationalist perceptions and civil war experiences, especially in her novels. This work aims to analyse the autobiographical political elements and woman theme in Espina's novel Retaguardia on the basis of Spanish Civil War, by means of literary expressionism on the writer.

Key Words: Espina, Retaguardia, woman, civil war, Franco, Spanish literature.

Güçlü bir monarşik ve Katolik yapıya sahip olan İspanyol İmparatorluğu, XVI. yüzyılda dünyanın en büyük sömürge gücüyken yaklaşık üç yüzyıl sonra Fransa'nın işgaline uğramasıyla başlayan bir zayıflama sürecine girmiştir. İspanya'nın Latin Amerika'daki sömürgelerinin bağımsızlıklarını ilan ettiği, uzun ömürlü olmasa da ilk Cumhuriyet deneyimini yaşadığı, ardından denizaşırı topraklarını tamamen yitirdiği XIX. yüzyıl salt siyasi değil toplumsal olarak da ülkeyi alışık olmadığı bir yapıya dönüşmeye mecbur kılmıştır. 1936-39 yılları arasında Falanjistler ve Cumhuriyetçiler arasında yaşanan, farklı ülkelerden gönüllülerin de katıldığı kanlı iç savaşın

\footnotetext{
1 Ankara Üniversitesi Sosyal Bilimler Enstitüsü İspanyol Dili ve Edebiyatı Anabilim Dalı doktora öğrencisi. celikelzeynep@gmail.com ORCID: 0000-0002-0014-0826
} 


\section{9alesto \\ MOLESTO: Edebiyat Araştırmaları Dergisi}

ardından diktatör General Francisco Franco, İspanya’nın idaresini öldüğü 1975 yılına kadar elinde tutmuştur. Toplum içinde ülkedeki aydın kesimin de taraf haline geldiği bu karmaşık dönemde sanat eserlerinin de söz konusu tarihsel, siyasi ve sosyal gerçeklerle iç içe olduğu, sanatçların siyasi görüşlerinin ve kişisel deneyimlerinin de etkisiyle gerçekleştirdikleri sanatsal üretimin dönemsel olarak kimi dönüşümlere uğradığ1 görülmektedir. Bu dönüşümlerin sosyo-kültürel boyutunun önemli örneklerinden birini, dönemin önde gelen kadın yazarlarından Concha Espina'da izlemek mümkündür.

Roman, öykü, şiir ve tiyatro yazarı olan Espina 1869 yllında İspanya’nın Santander kentinde, varlıklı bir ailenin çocuğu olarak dünyaya gelmiştir. Hem annesinin hem babasının oldukça varlıklı, mülk sahibi ailelere mensup olmasının etkisiyle, yazar geniş ekonomik ve eğitim olanaklarına sahip olmuş, kendi deyimiyle “burjuvažinin tadın çıkarmıştır." (Bretz, 1980: 13) Çocukluğunda evde ve manastırda eğitim gören ve annesinin teşvikiyle ilk şiiri 12 yaşındayken yerel bir gazetede basılan Espina dini bütün bir ortamda yetiştirilmiş, ailesi gibi kendisi de kilise ile yakın ilişki içinde olmuştur. İlerleyen zamanlarda dini referanslar kurgusal ve kurgu dışı yapıtlarında pek yer bulmasa da yazarın geleneksel toplum değerlerine bağlllı̆̆1 siyasi görüşüne ve eserlerine yoğun biç̧imde yansımıştır.

Annesinin ölümüyle sarsılan Espina babasının iflas etmesinin ardından, bir nevi arayış içindeyken, Şili doğumlu İspanyol iş insanı Ramón de la Serna y Cueto ile tanışmıştır. Yazar bir süre sonra ailesinin yatırımların takip etmek üzere Sili’ye gitmesi gereken Ramón de la Serna ile evlenmiş ve çift Şili’ye göç etmiştir. Eşinin işleri kötüye giderken Espina ekonomik bağımsızlığına doğru ilk adımlarını burada şiirlerinin yerel gazetelerde basılmasıyla atmış, ardından birçok Şili ve Arjantin gazetesine haber metinleri ve makaleler hazırlayarak çalışmalarını sürdürmüştür. Espina'nın kızının ifadesiyle "karısınm artan bağımsıəliğm bazmedemeyen otoriter kocamn baskısı" (Maza, 1969: 72) arttıkça iş ve ev hayatının dengesini tutturmakta zorlanan Espina, eşinden ayrılmayı düşünmüşse de bunu Şili'de, memleketinden uzakta yapmak istememiştir. 1898 y1lında ailesiyle birlikte İspanya'ya dönen ve eşinin ailesinin yanına yerleşen yazarın burada önce 1903 yılında Cervantes'in Don Quijote adlı romanındaki kadın karakterleri konu edinen makalesi, ertesi yıl ise ilk şïr kitabı Mis flores yayımlanmıştır. Bu dönemde şiirler ve Arjantin gazetelerine makaleler yazmaya devam eden yazarın mahlas kullanması yazınsal üretimi konusunda eşinin veya ailesinin müdahaleci bir tavırda olduğu biçiminde yorumlanmaktadır. (Bretz, 1980: 16) Espina, La riada adlı öyküsüyle yerel bir yarışmada birincilik elde etmesinin ardından ilk romanı La niña de Luそ̧mela için çalışmaya başlamıştır. Espina için romanının taslaklarının eşi tarafından yırtılıp atılması bir dönüm noktası teşkil etmiş (a.g.e.: 17), bu olayın ardından yazınsal başarısıyla ters orantılı biçimde ilerleyen evliliğini 1908 yılında 


\section{rsalests \\ MOLESTO: Edebiyat Arașturmaları Dergisi}

sonlandırarak dört çocuğu ile Madrid'e yerleşmiştir. Dönemin yasal düzenlemeleri gereği eşinin izni olmaksızın ev dahi kiralaması mümkün olmayan yalnız bir kadın olarak türlü güçlükler yaşayan yazar ailesinden maddi bir varlık da kalmadığından, kitap satışlarını artık yazınsal başarının yanı sıra geçim kaynağı olarak değerlendirmek zorundadır. 1909 yılında La niña de Lužmela, hemen ardından Despertar para morir ve Agua de nieve başlıklı romanları yayımlanan Espina artık kendi ismiyle basılan romanlarının satışından elde ettiği gelirle yaşamını sürdürebilir duruma gelmiştir. 1914 yılında La esfinge maragata adlı romanıla İspanya Kraliyet Akademisi tarafindan Fastenrath Ödülü’ne layık görülen ve dönemin entelektüel çevresinde gördüğ̈̈ ilgi artan yazar, Gerardo Diego, Federico García Lorca, Santiago Ramón y Cajal, José del Río Sainz gibi şair ve yazarların da övgüsünü kazanmıştır. $^{2}$

O dönem yılda en az bir roman, şiir veya öykü kitabı yayımlanarak yazınsal çevrelerde popülerleşen Espina’ya 1927 yılında İspanya Kraliyet nişanı ${ }^{3}$ verilmiş, ertesi yıl ise Kral XIII. Alfonso'nun kültür ataşesi olarak atanan yazar A.B.D., Kanada, Küba, Dominik Cumhuriyeti ve Porto Riko’ya seyahat ederek çeşitli etkinlikler düzenlemiştir. Yazarın adı dokuz kez Nobel Edebiyat Ödülü için önerilmiş, 1926, 1929 ve 1931 yıllarında adaylık elde etmiştir.

İspanya'da 1931 yllında gerçekleștirilen seçimlerde Cumhuriyetçilerin elde ettiği zaferle, monarşinin artık İspanyol halkı tarafindan istenmediği söylemi yaygınlaşmıştır. Bundan birkaç gün sonra Kral XHI. Alfonso tahttan indirilerek ülkede II. Cumhuriyet ilan edilmistir. 1923-1930 y1llar1 arasında başbakanlık yapan aristokrat diktatör Primo de Rivera’yı destekleyecek kadar sağ görüşe

${ }^{2}$ Genel olarak ulusal değerlere ve doğa unsurlarına yapıtlarında yer vererek İspanya’yı yücelttiği görüşüyle övgü toplayan Espina’ya yöneltilen olumsuz eleştiriler de dönemin edebiyat yayınlarında yer bulmuştur. Bu yorumlar yazarın oğlu tarafindan "bilhassa kadın biryaz̧ar olması nedeniyle kendisine gösterilen ilginin yadırganması" olarak değerlendirilmiş, "yapıtlarmın Hristiyan değerleri önceleyen siradan anlatılardan başka bir şey olmadiğg yorumlar, yaz̧arn başarlarna düsmanllk duyan 'yaz̧nsal oluşum'a mal edilmişstir." (Espina, 1955: X) Bu bağlamda Espina'nın bir anısına değinmek yerinde olacaktır. Espina yeni basılan ilk romanı La niña de Lu₹mela’nın imzalı bir kopyasını, kendisine verilen tavsiye doğrultusunda, İspanyol yazar ve eleştirmen Azorín’e gönderir. Çünkü Azorín dönemin önde gelen yazarlarından olmasının yanı sıra İspanya’nın en meşhur gazetelerinden $A B C$ de yazmaktadır. Espina, yapıtlarına eleştirmenlik kariyeri boyunca hiç değinmeyen Azorín’e ithafen imzaladığı kopyayı yıllar sonra bir sahafta bulduğunda kadın yazarlara verilen değeri daha iyi anladığını belirtir. (Renaciminto, 1928: 20)

31792 yllında İspanya Kralı IV. Carlos’un emriyle verilmeye başlanan söz konusu nişan "çalışmalar, görünüşü ve meziyetleriyle bemcinslerine örnek olacak asil kişilere" verilmektedir. (Molas i Ribalta, 2001) Yazar otobiyografisinde "görüslerinin esasım monarşi teşkil etmese de Kral XIII. Alfonso'ya, kişisel evsafina ilaveten büyük minnet duyduğunu” yazmıştır. (Renaciminto, 1928: 15) 


\section{rsalests \\ MOLESTO: Edebiyat Arașturmaları Dergisi}

mensup olan Concha Espina için bağlı olduğu ulusal değerlerin en büyük temsili olan Kralın tahtından indirilmesi ve ertesi yıl ülkeyi terk etmek zorunda bırakılması şoke edici olmuştur. Buna mukabil yazar, işçi haklarını önceleyen, eşitlikçi ve sol görüşlü II. Cumhuriyet'e alenen karş1 çıkmayan nadir gelenekçi aydınlardan biridir. (Chica, 2016) Bunun temel sebebinin, II. Cumhuriyet'in başlıca icraatlarından birini, yazarın öz yaşamında da olumlu etkileri izlenen, kadınlara kamu hizmetlerinde çalışma, boşanma ve velayet konularında geniş haklar tanıyan yasa değişikliğinden ileri geldiği görüşündeyiz. Zira yazarın Şili’den İspanya’ya dönüşünü müteakiben eşinden boşanması bu sayede mümkün olmuştur.

Siyasi olarak desteklemediği ancak itirazda da bulunmadığı II. Cumhuriyet, ilk yıllarında Espina'nın hakkını teslim etmiş gibi görünmektedir. Bu dönemde yazarın geleneksel ve ulusal değerlerin yüceltildiği üç yeni romanı (Entre la noche y el mar, Candelabro, Flor de ayer) basılmış, ayrıca 1935 yılında Lima'nın kurtuluş törenleri için Cumhuriyetçi İspanyol hükümetinin temsilcisi olarak Peru'ya gönderilmiştir. Ne var ki ülkedeki siyasi karışıllık şiddetlendiğinden, yazar Lima'dan döndüğünde çocuklarıyla birlikte memleketi Cantabria’ya gitmeye karar vermiştir.

Espina 1936 yılında İspanyol İç Savaşı patlak verdiğinde ailesiyle birlikte memleketi Santander'de bulunmaktadır. Siyasi eğilimi malum yazarın iki oğlu da Falanjist orduya katılınca Cumhuriyetçilerin kontrolü altındaki Santander'deki yaşamı güçleșen Espina ve ailesi başkent Madrid'e dönmeye çalışmış ancak başaramamıștır. Bu dönemde milislerce sorgulanması, evinde arama yapılması gibi hadiselerin de etkisiyle Franco'ya olan inancı kuvvetlenen yazarın artık tek gelir kaynağı olan yazınsal üretimi de yayımlanamaz olmuştur. Evinin aranması sırasında delil teşkil etmemesi için yazdıklarını yakmak zorunda kalan Espina tutuklanma ve ev hapsi cezalarının yanı sıra çocuklarıyla birlikte, esasen toplumun geri kalanından farksız biçimde, geçim sıkıntısına düşmüştür.

Santander 1937 yılının Ağustos ayında Frankist kuvvetlerce ele geçirilerek "kurtarılınca" yazar San Sebastian'daki oğlunun yanına taşınmışır. Bu yıllarda görme yetisini yitirmeye başlamış, yazınsal üretimi seyrekleşmiştir. 1942 yllında El mas fuerte adlı romanının basılmasının ardından dördüncü kez Nobel Ödülü'ne aday gösterilmiş ancak ödül Şilili şair Gabriela Mistral'e verilmiştir.

Concha Espina "içinden geçenlerin dı̧sarı aktarlması sırasında hata meydana gelmesinden çekindiŭg için yapıtlarm bir başkasma dikte ederek yaz̧may reddetmiş" (Chica, 2016) ancak yazmaya devam etmek istediğinden, şerit biçiminde kesilmiş kartonlar ile bir sistem oluşturarak görmemesine rağmen yazmaya çalışmıştır. Geçirdiği göz ameliyatları fayda sağlamayan yazarın son yapıtı 1953 yılında basılan Una novela de amor adlı roman olmuştur. 


\section{9alestos \\ MOLESTO: Edebiyat Araşturmaları Dergisi}

Amerikan Hispanik Birliği’nde başkan yardımclluğ yapan ve Amerikan Sanat ve Edebiyat Akademisi'nin onursal üyesi olan Espina henüz hayattayken memleketi Santander'de onurlandırılmıs, bir parka ismi verilerek heykeli dikilmiş, doğduğu belde Mazcuerras'ın ismi, ilk romanı La niña de Lužmela onuruna Luzmela olarak değiștirilmiştir.

Concha Espina’nın yazınsal üretimi dönemsel olarak değerlendirildiğinde dikkat çeken özelliklerden biri eski ve yeniyi, geçmiş ile geleceği dengeli bir yap1 içerisinde sunması olarak karşımıza çıkmaktadır. Toplum değerlerine ve geleneklerine bağlılı̆̆ını sosyal, siyasi ve yazınsal eğilimlerinin temeline oturtan yazarın romanlarının en popüler olduğu ve satışlarının yüksek seyrettiği dönemlerde hakkında yazılan eleştirilerin ortak özelliği, yazarın klasik ve geleneksel İspanya'yı yansıtmaktaki başarıyı modern ve yeni olana da yer vermekte göstermesi olmuştur. (Renacimiento, 1928) Geleneğe sayg1, ülkenin temelini teşkil eden toplum değerlerinin muhafazakâr biçimde savunulması gibi unsurları kullandığı romanlarında aynı ölçüde zamanın ruhunu da yakalayabildiği belirtilmiştir. Yazarın öz yaşamında da bu çizgiyi takip etmesi övgü aldığı bir başka boyut olmuştur. Babasına emeklilik hayatı geçirdiği kasabada çocuklarıyla birlikte sıklıkla ziyarette bulunması, edindiği başarı ve ünün yanında memleketine ve doğa hayatına olan bağlllı̆̆ını sürdürmesi, tüm bunlarla beraber güncel gelişmeleri takip etmeyi de ihmal etmemesi övgü toplamıştır. Örnekse, pilot olan çocukluk arkadaşının davetine icabetle, havacilık alanında henüz gelişmekte olan İspanya'nın küçük uçaklarıyla yapılan denemelere katılması modern bir davranış olarak ilgi görmüş (Bretz, 1980: 19) ve bu deneyimin yansıması olarak Las alas invencibles romanının konusunu bedensel engelli bir kadının İç Savaş sırasında ilk kez bir savaş uçağına binmesi oluşturmuştur.

Genel olarak realizm ve geç romantizm akımlarına dahil edilen, kendisininse "temeli realist, dokunakl yan dramatik" olarak nitelediği (Renacimiento, 1928: 16) İngilizce, Fransızca, Almanca, İtalyanca, Çekçe ve Rumence dillerine çevrilmiş yapıtlarına Espina ülkedeki gelişmelerin yaşamında ve görüşlerinde meydana getirdiği değişimi de aktarmıştır. Ona göre; İspanya tarihini, toplumunu, toplumun Katolik ve muhafazakâr yapısını, kısaca İspanya'yı kutsal kılan ulusal değerleri yeterince öncelemeyen Cumhuriyetçi kesim, bunun yerine siyasi ve dini olgulara daha özgürlükçü bir anlayışla yaklaşarak İspanyol İç Savaşı'na giden yolda rol oynayan unsurlardan biri olmuş gibi görünmektedir. Bu noktadan hareketle, İspanyol İç Savaşı'nın ülkede yarattı̆̆1 siyasi, toplumsal ve ekonomik yıkıntıya olumsuz bireysel deneyimi de eklenince yazarın Falanjist görüşe daha da sarıldığ1 görülmektedir. İç Savaş öncesi yayımlanan öykü ve romanlarında aleni bir siyasi görüş sunmak yerine ulusal ve geleneksel toplum değerlerini öne çıkarmış, işçi sınıfının sorunları da dahil olmak 


\section{9alestos \\ MOLESTO: Edebiyat Araşturmaları Dergisi}

üzere toplumsal eşitsizlikler ve haksızlıkları ele almış, ayrıca İspanyol toplumunun yaşadığı sorunlar karşısında duyarsız bir tavır takınan varsıl kesimi eleştirmiştir. İç Savaş sırasında ve sonrasında yazdığı romanlarda ise toplumsal gelenek ve değerlerin yerini belirgin bir ideolojiye, Falanjist bir anlatıya bıraktığı dikkat çekmektedir. Varlıklı bir ailenin çocuğu olan Espina için, komşularından yiyecek ve giysi yardımı alma aşamasına gelmesinin de ülkenin içinde bulunduğu siyasi çıkmazın da müsebbibi Cumhuriyetçilerdir. Bu yaklaşımla İç Savaş sırasında yazdığı üç romanı Retaguardia, Luna roja ve Esclavitudy libertad’n en önemli ortak özelliği, otobiyografik niteliklere ilaveten döneme ilişkin tarihi ve siyasi unsurları taraflı biçimde sunmalarıdır. İspanyol toplumunun İç Savaş döneminde yaşadığı derin kutuplaşma ve yaygın partizan anlayış gibi birtakım gerçekliklerin yanı sıra Cumhuriyetçilerin düşüncesizce hareket eden ve onur, şeref gibi insani değerlerden yoksun; Frankist Ulusalciların ise gurur arz eden ideal profillerde okura sunulduğu görülmektedir. Trajik olaylar apolitik veya Falanjist karakterlerin başına gelirken bunların acı ve mağduriyetinin nedeni yine Cumhuriyetçilerdir.

Concha Espina’nın yapıtlarındaki kadın karakterler, savaş dönemi romanlarında genellikle anne, öğretmen veya hemşire gibi toplumsal bir temsile sahip rollerde karşımıza çıkmakla birlikte dönemsel olarak farklılıklar göstermiştir. Yazarın bütünüyle Falanj destekçisi olduğu yıllarda eserlerindeki kadın karakterler kaderleri ve nitelikleri ile bir vatan özdeşleştirmesi çerçevesinde sunulurken, kendilerinden kocalarını mutlu etmelerinin yanı sıra anne olarak ülkenin geleceğine katkı sunacak evlatlar yetiştirmeleri beklenir. Bir aşk ilişkisi içinde sunulan kadın karakterler ise erkek karakterin hayalinde, sonrasında edineceği anne rolüyle yer alır. Entre la noche y el mar, Candelabro, Flor de ayer, Princesas del martirio ile Alas invencibles başlıklı romanları bu duruma örnek teşkil etmektedir.

Espina'nın İç Savaşın sonlanmasının hemen ardından yayımlanan La otra ve Moneda blanca romanlarında Katolik, Frankist ve İspanyol milliyetçisi karakterlerin yüceltildiği, El fraile menor, La segunda mies gibi öykü ve şiir kitaplarında ise savaşın toplum üzerindeki etkilerinden ziyade bireylerin yaşamına yansıması üzerinde durduğu dikkat çekmektedir. Savaş imgesine tarafsız olmasa da uzak bir bakış açısıyla değinmesi şüphesiz savaşın verdiği bitkinlik ve bıkkınlıktan kaynaklanan yazar aynı zamanda bu korkunç sürecin Falanjist idarenin zaferiyle sonuçlanmasından da memnundur.

İç Savaş sonrası ülke yönetimini ele geçiren Franco'nun kadınları baskılamaya yönelik sosyal ve yasal düzenlemelerinin kısıtlayıcıllğı giderek artmıştır. Yine de bu tutucu yönetime olan inancinı sürdüren Espina'nın o dönem Falanj destekçiliğini yapıcı eleştirilerle sürdürdüğü görülmektedir. Temelde aynı siyasi görüşü paylaştığı dikta rejiminin kadınlara yönelik uygulamalarıyla hemfikir 


\section{rsalests \\ MOLESTO: Edebiyat Arașturmaları Dergisi}

olmadığını yazarın kadın karakterlerin hareket tarzını dönüştürmesinde izlemek mümkündür. İspanyol milliyetçisi retoriğin ve Franco yanlısı vurguların azaldığı El mas fuerte ve Victoria en América başlıklı romanlarında, kadın karakterler toplumsal cinsiyet temelli yazgıları hilafina hareket eder, Falanjist idarenin yerleştirmeye çalıştığı sosyal düzene ve kadın haklanını yok sayan hukuk sistemine karşı bir duruş sergiler niteliktedir. Yazarın bu yaklaşımıyla, Frankist devlet yapısının kadın haklarına ilişkin uygulamalarının yanlışlığını kabul ederek çözümü bunların düzeltilmesinde gördüğünü tespit etmek mümkündür. Nitekim Espina o dönemde bilhassa İspanyol Falanjı Kadın Kolları'n1 ${ }^{4}$ (Sección Femenina de Falange Española) eleştirmiş, topluma fayda sağlaması için Sección Femenina’nın uygulamalarında değissikliğe gitmesi gerektiğini gündeme getirmiştir. Yazar bu yaklaşımı nedeniyle daha sonra Franco taraftarı aydınlarca dışlanmış ve Falanjı yeterince desteklemediği yönünde eleştirilere maruz kalmıştır.

Concha Espina’nın, çalışmamıza kaynak teşkil eden ve sözcük olarak "artçı” anlamına gelen Retaguardia başlıklı romanını İç Savaş sırasında, Santander'de Cumhuriyetçiler egemenken, ev hapsinde tutulduğu dönemde kaleme almış ${ }^{5}$, evinde sıklıkla polis araması yapılması nedeniyle yazmış olduğu bölümleri bahçeye gömerek saklamak zorunda kalmıştır. (Espina, 1955: 1017) İlk baskıs1 1937 yilında yapılan Retaguardia’nın hikayesi kurgusal Torremar sehrinde, şehrin Cumhuriyetçilerin egemenliği altında olduğu dönemde geçmekte olup yapıt toplam dokuz bölümden oluşmaktadır.

Roman, Alicia Quiroga adlı genç kadının, Cumhuriyetçilerce kaçırılan sevgilisi Rafael Ortiz’i aramasını konu edinir. Alicia'nın bu arayışına yardım eden kardeşi Felipe bir müddet sonra, kayıp

\footnotetext{
4 İspanya'nın diktatör başbakanı Primo de Rivera'nın kızı olan Pilar Primo de Rivera'nın 1934'te partinin kadın kolları olarak kurduğu Sección Femenina 1939'da hükümet tarafindan resmi bir kurum haline getirilmiştir. İdeal Katolik, geleneksel ve tutucu toplumun yapıtaşının aile, onu kuranın da kadın olduğu anlayışıyla toplumsal cinsiyet rollerini tanımlayan "Sección Femenina mevcudiyeti İspanyol kadmmmn temiz, çocuklarn sağhkl, toplumun huzurlu olmasın sağlayacaktı. Falanjin benimsediği yeni düzen kadin bažlarmm alguladĭg gibi yermiyor, aksine onu batıdan kapitalizmin, doğudan komünižmin sıkıştırdiğz toplum içinde vahşsi yaşam koşullarndan koruyordu.” (Gallego Méndez, 1983: 73)

5 Concha Espina'nın kızı Josefina de la Maza'nın annesini konu edinen anı kitabında, yazarın Retaguardia’yı yazmaktayken tutuklandığ1 gün anlatılır. Cumhuriyetçiler tarafindan sorgulanan Espina'ya Küba, Şili ve Fransa'dan hükümetler ve farklı kuruluşlardan iltica daveti almasının nedeni, İspanya'da niçin bu denli 'mutsuz' olduğu sorulur. Yazar durumu teyit ederek Santander'den ayrılmak istediğini söyler. Kendisine, isyancı faşistler arasında olduğu tespit edilen oğlu nedeniyle yerel makamlar tarafından il sınırları dışına çıkmasının yasaklandığı yanıtı verilir, ardından yazar ev hapsine mahkum edilir. (Maza, 1969: 201-202)
} 


\section{realests \\ MOLESTO: Edebiyat Arașturmaları Dergisi}

Rafael'in kardeşi Rosa'ya âşık olur. Yapıtın sonunda Rafael tüm çabalara karşıı bulunamaz, Felipe cepheye savaşmaya giderken Alicia sevgilisinin faili meçhul biçimde öldürüldüğ̈nü kabullenir.

Retaguardia'nın geçtiği şehir Torremar olarak sunulmakla birlikte bu şehir yazarın İç Savaş sırasında romanı kaleme aldığı, Cumhuriyetçilerin kontrolü altındaki Santander'den izler taşımaktadır. Alicia Quiroga ve kardeşi Felipe'nin ailesi, Torremar'daki Cumhuriyetçi yapının önde gelen mensuplarındandır. Rafael Ortiz ve kardeşi Rosa ise Quirogalarla benzer biçimde orta-üst sınıfta yer alır ancak Franco destekçisidir. Farklı görüşteki bu iki aile yapıt boyunca toplum içindeki konumları ve siyasi eğilimleriyle örtüşen nitelikleriyle kıyaslanırlar. Yazarın kendi görüşlerine uygun biçimde, ulusalcı Franco taraftarlarını güzellemeyle ele alırken Cumhuriyetçi kesimi aksi istikamette, bencil ve sonradan görme sıfatlarıyla sunduğu görülmektedir. Örneğin Quirogaların evi "aşır gösterişli" (a.g.e.: 1019), babaları "karısı terzi yamağı olmakla beraber kendi denizcilik ișlerinde mübim yerlerde olan yeni żengin”, genç kız Alicia ise "kendini eğlemekten başka şeye yaramayan bir özgürlük içinde eğitilmiştir." (a.g.e.: 1026) Alicia sevgilisi Rafael'in annesine hayranlık duyar; kadının yüce gönüllü ve ölçülü halini, altında çalışanlara karşı düşünceli tavırlarını gördükçe onu kendi annesiyle kıyaslar. (a.g.e.: 1027) İç Savaş başlamış olmasına karşın Quiroga Ailesi karaborsa ve sahip olduğu egemen Cumhuriyetçi çevre sayesinde lüks bir yaşam sürer, sosyal ve ekonomik olarak yükseliştedir. Bu ailenin komünizme bağllikları dahi göstermeliktir. (a.g.e.. 1029) Buna mukabil Ortiz Ailesi, muhafazakâr ve Falanjist olduğu için ekonomik imkanları mevcut koşullar altında kısıtlanmıştır. Ortizler, Franco birliklerinin yanında savaşmak üzere cepheye giderken Cumhuriyetçilerce tutuklanan oğulları Angel'in ardından diğer oğulları Rafael'i de kaybedecektir.

Retaguardia'da yazarın ilk kez toplumsal sınıfların ayrıksılığını seçkinci bir yaklaşımla sunduğu görülmektedir. İspanyol toplumunu o yıllarda tanımlamanın ancak siyasi ayrışma olgusu ile bir arada ele alındığında mümkün olduğu, ayrıca yazarın varsı bir aileden geldiği doğru olmakla birlikte Espina önceki yapıtlarında Retaguardia'daki kadar sert sınıfsal ayrımlarla yer vermemiş, nispeten dengeli ve kapsayıcı temsiller sunmuştur. Her ne kadar toplumdaki iç çatışmanın ekonomik sınıflarla bağlantılı olmadığ1 iletisini okura sunsa da (a.g.e.: 1023) Falanjistleri ve Cumhuriyetçileri kendi siyasi görüşü doğrultusunda tanımlamaktan geri durmaz: "İspanya'nın iki yarısı için karşı tarafi analiz, etmek ilginc olacaktır. Kariyer sabibi, üniversite mezunu, sanaţ̦ ve doktorlar askerin yannda yer alırken Kızıllarm ardında bir avuc berber, eğitimsiz, kıymet bilmez, kıskanç fabrika iş̧̧isi vardır." (a.g.e.: 1051) Quiroga ve Ortiz Ailelerinin gösterdiği toplumsal ve ekonomik değişim de bu

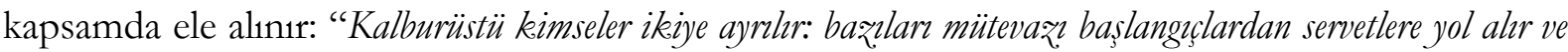
bunlar sadece kendi çıkarlarm gözetirler. Baz̨laryysa doğustan asildir, toplum içinde sevgi ve saygı görür ve iyiliği 


\section{9alests \\ MOLESTO: Edebiyat Araşturmaları Dergisi}

berkesle paylaşmak isterler." (a.g.e.: 1027) Bu ayrıştırıcı anlatı karakterlerin dış görünüşü ile de perçinlenir: "tarifsiz, mucižleri başaran İspanyol halkınm (...) tutku dalgasiyla yü̈kselen esmer kudretidir." (a.g.e.: 1063) İspanyol milliyetçiliğini daha önceki eserlerinde başka uluslara mensup karakterlere yer verecek kadar hoşgörülü ve bütüncül bir anlayışla sunan Espina burada anlatıyı kapsayıcılık yerine ilginç biçimde 1rkçılık düzeyine çekerek İspanya'daki Cumhuriyetçilerin Sovyetler Birliği ile, yani “esmer” İspanyolların karşıtı olan "beyaz” tenli Ruslarla kurduğu "kızıl” bağlantıya işaret etmektedir.

Romandaki ana karakterler duygusal ilişkilerine ilaveten siyasi zeminde de etkileşim halindedir. Alicia Rafael'den etkilenirken, Felipe de Rosa ile vakit geçirdikçe, gençler Quiroga Ailesi'nin çocukları olarak taşıdıkları Cumhuriyetçi anlayışı bir kenara bırakır ve İspanyol milliyetçisi olma yolunda ilerler. Bir noktada Felipe'nin babasına adeta meydan okuduğu görülmektedir: "Insanlarm elinden silablarm, paralarmı, inançlarm, evlerini aldını. Bunları da balk demeye cüret ettiğiniz cabil vesvesecilere silah, saray ve sanat eserlerini peşkeş̧ çekmek için kullandinı. Kendi süslü siyasetine bile katkısı olmayan, kimseye biçbir şeyini vermeyen sen başkalarnm elindekini almayı kendine hak mo görüyorsun? Adalet bu mu? Özg̈̈rlïk bu mu?’ (a.g.e.: 1029) Çiftlerin gerek Rafael'in kaybolmasından önceki birliktelik dönemlerinde gerekse Rafael'i aradıkları sırada, Alicia ve Felipe'nin, sevgilileri Rafael ve Rosa'nın etkisiyle Cumhuriyetçi görüșten uzaklaşması romanda bir süreç olarak sunulmuştur. Aynı şekilde Alicia, Rosa ve Felipe'nin Rafaeli bulmaya yönelik arayıssı da yapıtın tamamına yayılmıştır. Yazarın bu yolla okurda, ülkenin içinde bulunduğu karışıklığa da karşılık gelecek şekilde bir devamlılık ve umut hissi uyandırmayı amaçladığını söylemek mümkündür.

Concha Espina’nın gelenekçi ve Falanjist anlayışının yapıttaki yansıması kadın izleğinde de karşımıza çıkmaktadır. Retaguardia’nın kadın karakterleri yazgısı, çabası ve direnciyle dönemin İspanyası ile ortak özelliklere sahip biçimde sunulmuştur. Yapıttaki ulus-kadın özdeşleştirmesi üç boyutta tespit edilebilmektedir: kadın, doğa ile bağlantılı ve bu nedenle etkileyicidir, savaş nedeniyle acı çeker ve eril kuvvet tarafindan korunur.

Yapıttaki iki ana kadın karakter Alicia ve Rosa bekar olmakla beraber müstakbel annelik nitelikleri sayesinde toplumun şekillenmesine katkı sunması beklenir pozisyondadır. Doğa tarafından bahşedilen doğurganlıkları onları, tıpkı vatan gibi doğası gereği etkileyici kılmaktadır. Karakterlerin doğayla bireysel bağlantısı ise deniz ve çiçek imgeleri üzerinden sunulmuştur. Rosa, isminin de ifadesiyle, gül gibi güzel, el değmemiş, masum, sade ve kırılgan niteliktedir. Alicia sevgilisi Rafael ile mutlu zamanlarını sahilde yaşamış, “denizş̧abitleri olmuş” (a.g.e.: 1025) ve bu nedenle denize özel bir anlam yüklemiştir. Burada deniz imgesinin Alicia karakteri nezdindeki devinimi dikkat 


\section{realests \\ MOLESTO: Edebiyat Araşturmaları Dergisi}

çekicidir. Sevgilisi Rafael yanındayken mutlu anlarına şahit olan deniz ilaveten Alicia'nın kardeşi Felipe'nin Cumhuriyetçilerin elinden bir tekneyle kaçmasıyla da olumlanmaktadır. Ancak yapıtın sonunda Alicia Rafael'in Cumhuriyetçiler tarafindan denize atılarak öldürüldüğüne, son kertede "deniz̨in sevgilisine mezar olduğuna" (a.g.e.: 1072) kanaat getirmiştir.

Kadın karakterlerin vatanla özdeşleştirilmesinin diğer boyutu acı çekmesi olarak karşımıza çıarken bu durumdan yine yazarın siyasi eğilimi doğrultusunda Cumhuriyetçiler sorumlu tutulmaktadır. Etrafı sarılmış, kötü muameleye ve istismara uğrayan kadın karakterlerin mağduriyeti, Santander'de Cumhuriyetçilerin baskısı altındaki huzursuzluğa tekabül etmektedir. İspanya'nın kederinin yansımasıyla kadınlar geçmişteki mutlu günlerini özlemle anarken mevcut durumda gözü yaşlıdır ve acı çekmektedir. Toplumsal cinsiyet algısının ön planda olmadığı bir cinsiyetçi yaklaşım sunan yazar, Alicia'nın Rafael'i arayışında bedenselleşen çaba ve fedakârllğı acının kabul edilmesi ile sonuçlandırır. Bu, o dönem Sección Femenina'nın öne sürdüğ̈̈, acı çekmenin olgunlaşmak ve refaha ermek için gerektiği savı ile örtüşen bir yaklaşımdır. Fedakârlık olgusunu, kaybolan sevgilisini aramaktan yorgun düşen Alicia'nın fiziksel olarak da taşıdığı gözlemlenmektedir. Zayıflamış kadının "ateşi olduğu zavnf yü̈zünden bellidir" (a.g.e.: 1021), "göz. altlan çökmüstü̈r" (a.g.e.: 1034), "mum gibi erimektedir." (a.g.e.: 1058) Buna mukabil tıpk1 iyi bir İspanyolun vatanın Cumhuriyetçilerden kurtuluşunu teminen mücadeleyi sürdürmesi gerektiği gibi Alicia da bu güçsüzlügünün kendisini durdurmasına izin vermeyecek, aradığını bulmak ve mutluluğa ulaşmak için çaba sarf etmeye devam edecektir. Aynı doğrultuda Rosa karakteri bir kardeşi (Rafael) kaybolmuş, diğeri (Angel) tutukluyken bu durumun sorumlusu olan Cumhuriyetçilerin yazıhanesinin yerlerini silmek zorundadır çünkü ancak bu şekilde geçimini sağlaması ve hasta annesine bakması mümkündür. Rosa bu mağduriyetleriyle acı çekmekte, fakat sebat etmeyi sürdürmektedir. Bu şekilde fedakârllk oranını yükselten kadın karakterlerin çektiği acıyla güçlenmesi yine vatanın durumu ile eşgüdüm halinde karşımıza çıkmaktadır.

Yazarın toplumdaki Falanjist-Cumhuriyetçi ayrımını belirgin biçimde sosyo-ekonomik sınıflarla ilişkilendirdiği romanda, kadın karakterlerin emeğinin anlamı da bu doğrultuda şekillenmektedir. Eskinin burjuvası, yeni dönemin temizlikçisi olan Rosa, Cumhuriyetçiler tarafından çalıştırılmakta ve "...mekan sahiplerinin yapılmasın zorunlu tuttuğu iş, akıl, sanat ve teamüle aykern en medeniyetsiz zalimlikti; Komünizmin idaresi altındaki Ispanya, toplum için, ashnda tarih, kültür ve Tanr tanı anlayıs için en anormal olaylarn altında ezilmekteydi." (a.g.e.: 1025)

Dönemin toplumsal cinsiyet rollerinin Falanjist anlayışla örtüştüğü bir başka husus, vatanın, dolayısıyla kadınların maruz kaldığı güçlükler karşısında erkek karakterlerin eylemlerinin temelini, 


\section{9alesto \\ MOLESTO: Edebiyat Araştırmaları Dergisi}

onları korumaya ilişkin gereksinimin oluşturmasıdır. Bu şekilde erkekler, hem vatanın hem kadının kurtarıcısı olma hedefiyle eril mevcudiyetlerini teyit etmiş olurlar. Sevgilisi Rafael kayıp olduğundan Alicia'nın koruyuculuğunu kardeşi Felipe üstlenmiştir. Ayrıca Rosa ile sevgili olmalarını müteakiben Felipe onun da kurtarıcısı olmak zorundadır. Bunun için Cumhuriyetçilerin yazıhanesinde temizlikçi olan Rosa'ya yeni bir iş bulmaya çalışır, hasta annesine bakmasında ona destek olur. Yapitın sonunda Falanjist cepheye savaşmaya giden karakter böylelikle erilliğini tam kapasiteyle icra etmiş görünmektedir. Felipe toplumsal cinsiyet rolünün gereklerini fazlasıyla yerine getirmesiyle dikkat çekmektedir. Bir erkek karakterin gerçeküstü görünme pahasına bu denli idealleştirilmesinin yapıttaki erkek karakter sayısının azlığından kaynaklandığ1 görüşündeyiz. Ana karakter Alicia'nın koruyucusu olması gereken sevgilisi Rafael ortada olmadığı gibi Alicia, Cumhuriyetçi ailesi nedeniyle İspanyol toplumunun kutsal değer, anlayış ve geleneklerinden yoksun yetişmiş olmasının da etkisiyle daha fazla kollanmaya muhtaçtır. Olayların geçtiği Torremar'ın da Cumhuriyetçilerin egemenliği altında olduğu ve kadınlara türlü mağduriyetler yaşattığ1 düşünüldüğünde yapıtın kurgusu kapsamlı ve kalabalık erkek mevcudiyetinden yoksun görünmektedir. Yazarın bu açığı, ataerkil toplumun yapıttaki eyleyici temsili olan Felipe'de tüm koruyucu ve kurtarıcı nitelikleri bir araya getirerek kapatmayı öngördüğünü tespit etmek mümkündür.

Retaguardia'da kadının vatanın kurtuluşunda rolü olduğu görüşünü yazar eril mevcudiyetin içinde de okura sunmak ister: "Ulusun kurtulusunda kadina ciddi bir görev dïser ve bu, kader kadin yücelttiksce daha da kaçmulmaz, hale gelir.” (a.g.e.: 1025) Ülkenin kurtuluşu için toplum tarafindan ortaya konulması beklenen kolektif çabaya katkısının yanı sıra kadının "esas kurtarıcı" olan erkeğe destek sunmak gibi bir ödevi de bulunmaktadır ve Alicia ile Rosa bunu yerine getirmektedir. Örnekse, kaybolmasından önce “ülkedeki karşılklı içinde Rafael'e buzur veren Alicia'dır (...) onunla zaman geçirmek Rafael için zor zamanlarm ilacı gibidir." (a.g.e.: 1025) Keza Felipe "Rosa'nun yeşil gözleri tarafindan her bakıșıyla koruma altındadır." (a.g.e.: 1042) Aynı çağrıșımla, Felipe'yi cepheye götürecek geminin sinyal 1şığı yine yeşil renklidir. Koruyuculuklarına ilaveten erkek karakterlerin kadınları zenginleştiriciliği de yine ilişkilerin faydalı yönüne örnektir. Rafael Alicia’ya sevgi ve mutluluk sunmakla kalmaz, kadını yüzeysel yaşantısından sıyrılıp hayatına anlam katmaya yönlendirir: "Dudaklarnndan dökülen ilk duay ögrreten de işkeenceci Cumburiyetçiler karşısında ses çıarmaya sevk eden de Rafael'di.” (a.g.e.: 1026) Aynı zamanda, Rafael Alicia'nın Katolik inancını kuvvetlendirirken liseden mezun olup üniversite öğrenimine yönelmesi için de teşvik edici bir yaklaşımdadır. Bu olgunun Espina’nın Falanjist anlayışın bir revizyona tabi tutulması gerektiğine dair düşüncelerinden kaynağını aldığı görüşündeyiz. Dönemin İspanyasında kadınların eğitim haklarını son derece kısıtlayıcı uygulamalar 


\section{9alests \\ MOLESTO: Edebiyat Araşturmaları Dergisi}

zemininde güçlükle icra edebildiği düşünüldügünde Espina’nın siyasi mekanizma olarak desteklediği ve katkı sunduğu Franco yönetiminin sosyal alanda bazı değişimler geçirmesi gerektiğine inandığı görülmektedir. Pekiştirici unsur Rafael de olsa eğitime önem veren ve öğrenim hayatına devam etmek için çalışan Alicia'nın kendisidir ve kadın karakter bu şekilde eylemlerinin sorumluluğunu alarak dönemin toplumsal cinsiyet kalıplarından da sıyrılmaya yönlenir.

Yapıtta geleneksel toplum yapısı ile örtüşür biçimde sunulan bir başka unsur kadın-erkek ilişkisidir. Bu noktada İspanyol toplumundaki yaygın anlayış yazar tarafindan muhafaza edilmiş, sevgili/âşık olan kadın ve erkek karakterlerin ilişkilenme biçimi gelenekselliğin sınırları dahilinde sunulmuştur. Bu, göz temasının başlangıcı, el temasının ise kat edilen bir aşamayı temsil ettiği biçimdir. Alicia ve Rafael için bakışmak "tarifsiz bir kesşin sürpriz̨ini, düsüncelerin sakl karmașasın barndıran derin bir eylem” iken Rosa ve Felipe'nin “aşkım başlatan, çünkü itiraf edilmeyen şsyleri yansıtan yegâne unsur'dur. (a.g.e.: 1026) Ellerin birbirine değmesi ile gerçekleşen fiziksel temas, karakterler için aşkın karşıllklı olduğuna delalettir; Rosa öpmesi için Felipe’ye ellerini uzatırken gözleri yaşlarla doludur çünkü en yüce duygulardan birini yaşamaktadır. (a.g.e.: 1052) Bu noktada ellerin hizmet etmeye karşl1k gelen bir metafor olarak da işlevselleştirildiğini söylemek mümkündür. Zira Felipe'nin Rosa'nın ellerini öpme isteği ilk kez, kadının Cumhuriyetçilerin merkezinde yerleri sildiğini ögrendiğinde uyanır: "... kan kaynayan genc o an o elleri öpmek için duyduğu gözle görülür heyecanım bastırmakta zorlandi; o elleri tutkulu bir icgüdüjle ok.sadi." (a.g.e.: 1038) Bu ifadeyle yazarın kadın-erkek ilişkisinde namus, şeref gibi ataerkil değerlerden sıyrılmış biçimde bir arzu ve fiziksel temas örneği ile örtülü bir cinsel çağrışım sunması geleneksel toplum yapısı içinde varlık gösteren unsurlara yenilikçi bir açıdan yer vermesi anlamı taşımaktadır. Bununla birlikte, aşk ilişkilerinin heteronormatif formatta evlilik ile neticelenmesi bir zorunluluktur. Espina'nın Franco ile en büyük ortak paydası olan geleneksel anlayıs temelinde toplumun dirliğini ve gelişimini temin eden, sağlam ve sürdürülebilir değerlerini taşıyan aileyi evlilik teşkil edecektir. Bu doğrultuda Alicia ve Rafael kilisedeyken "içinden geçtikleri koca salonda mutluluğu gö̈bebeklerinden okunan o sonsuz birlikteliğin, tutku ve bağlllı akdinin bayaliyle iş geçirirler". (a.g.e.: 1026) Aynı şekilde Rosa ve Felipe'nin “aşk için yeterince olgunlaşmıs yürekleri arasında evlilik bağı” kurulması öngörülür. (a.g.e.: 1053) Rosa’yı Felipe için "çekici kulan bashlica nitelikleri zarafeti ve ciddiyetidir (...) bu sayede henüz, erken de olsa ufukta bir evlilik hayal edilir." (a.g.e.: 1063) Yapıt iki çiftin evliliklerini okura sunamasa da yapıtın sonunda bu unsurun, bağllik duygusu zenginleştirilmiş yanıyla iki ilişkiye de sabitlendiği görülmektedir. Alicia sevgilisi Rafael’in kaçırıldığ1, denizde boğularak öldürüldügü düşüncesine ikna olmuş biçimde hayatının ilk ve son aşkına bir ömür bağlı kalacaktır. Bu hareket tarzı karakterin vatana, tarihine, geleneklerine bağl1lı̆̆ını 


\section{9ajegtos \\ MOLESTO: Edebiyat Araştırmaları Dergisi}

da temsil etmektedir. Ayrıca tek eşlilik anlayışı dönemin İspanyol toplumunda kaybedilen eşin/sevgilinin yerinin doldurulmaması doğrultusundadır zira evlilik çağı geçmiş bekar kadınların takdir gördüğü tek yönü bu tür bağlllıklar teşkil etmektedir. (Gonzalez-Allende, 541) Alicia’nın tek mutluluğu birlikteliklerini teşvik ettiği Rosa ve Felipe’nin ilişkisidir. Bu ilişkide de Felipe’nin ülkede Frankist zafer elde edilince Torremar’a dönerek Rosa ile evleneceği, yani tüm ana karakterlerin bağlılıkla kişisel yaşamlarını sürdüreceği vurgulanır. Alicia’nın yapıtın sonunda sergilediği olgunluk yine toplum içinde kadından beklenen hareket tarzı özelliklerindendir. Çaresizliğini ve Rafael’in öldürüldüğüne ikna olarak yenilgiyi kabullenmesine karşın gülümseyerek, sevgilisine olan bağl1lığını dile getirerek ve kardeşinin ilişkisinden duyduğu memnuniyetle arayışını sonlandırır.

Sonuç olarak, Concha Espina Falanjist bir aydın olmakla beraber Franco yönetiminin hatalı bulduğu uygulamalarını kendi siyasi görüşü ve inançlarından ayrı tutmayı bildiğini, İspanyol milliyetçiliği, Katolik değerler ve kadınların sosyal ve yasal hakları gibi konulara yapıtlarında dönemsel olarak farklı ölçülerde yer vermesiyle ortaya koymuştur. İç Savaş deneyiminin ülke siyaseti ve toplumunda bıraktığı hasarlara ilaveten Espina'nın bu dönemi karşıt görüşteki Cumhuriyetçilerin egemenliği altındaki Santander'de geçirmesi, bireysel olarak da yara almasına ve bu durumu yapıtlarında kimi zaman yazınsal anlamda tarafsızlık kaygısı taşımadan sunmasına neden olmuştur.

Ispanyol İc Savaşı sırasında kaleme aldığı romanı Retaguardia'da salt savaşın siyasi etkileri değil bu tarihi sürecin bireysel yaşamlara yansıması da gözlemlenmektedir. Yazar sorguya alındığ1, evinin arandığı ve ev hapsinde tutulduğu bu dönemi, muhafazakâr Falanjist tarafı olumlamak, dini ve toplumsal değerleri yok sayan Cumhuriyetçileri saldırgan, hain ve kötücül profilde sunmak suretiyle Retaguardia'da öz yaşam öyküsüne oldukça paralel bir anlatıyla sunmuştur. Ona göre vatanın Cumhuriyetçiler yüzünden içine düştüğü güç durumdan kurtulmasının yolu Franco'dan geçmekte ve kadınların da bu sürece aktif katılım sağlaması gerekmektedir. Romanda, Falanjist olduğu için kaçırılan sevgilisi Rafael'i arayan Alicia, netameli bir tutumdansa, kardeşi ve onun sevgilisi ile birlikte Rafael’i her şeye rağmen aramayı sürdüren, mücadeleden vazgeçmeyen profiliyle örnek bir kadındır. Bu, bir iç savaş yaşayan İspanya'da kadınlardan beklenen tutumla özdeştir; hem Franco hem sevgili/kardeş gibi unsurlarla temsil edilen eril kuvvete olan inanç, geleneksel toplum değerlerine bağllilk muhafaza edilirken, gelecek için evlenmek ve evlat yetiştirmek gibi yine vatana hizmet niteliğindeki eylemlere yönelik düşünceler devam etmektedir. Romandaki kayıp sevgili, sadece İspanya'nın değil yazarın da bir arayış içinde olduğunu temsil etmekle birlikte gelecek birtakım değişikliklere işaret etmektedir. Ülkedeki ikilemin, geçmişi önceleyen gelenekçi Franco yanlıları ile özgürlükçü ve yenilikçi Cumhuriyetçilerin çatışmasından ibaret olmadığının ayırdında 
olan yazar, boşanma ve eğitim gibi kadınların mahrum kaldığı birtakım hak ve özgürlüklerin toplumun muhafazakâr teamülüyle çelişse de gerekli olduğunu öz yaşamında bire bir deneyimlenmiştir. Retaguardia'nın sonunda Alicia karakterinin, sevgilisinin yokluğunu keder ve olgunlukla kabullenmesini, yine de ona bağllı̆̆ıyla yaşamaya devam edecek olmasını, yazarın İspanya'nın çıkmazı karşısında gerek kendisi gerekse toplum için işaret ettiği bir üçüncü çıkış yolu olarak değerlendirmek mümkündür. Alicia'nın tutumu, geçmişle bağlarını koparmayan ancak gerektiğinde değişikliğe uğraması mümkün olan, gelenekçi ama umutlu bir anlayışla geleceğe ve kurtuluşa yönelen bir yapıyı simgelemektedir.

\section{KAYNAKÇA:}

Bretz, Mary Lee, Concha Espina, Boston, Twayne Publishers, 1980.

Caballé, Anna, Breve historia de la misoginia: Antología y crítica, Editorial Ariel, 2019.

Canales, Alicia, Concha Espina, E.P.E.S.A., Madrid, 1974?.

Chica, Miguel Ángel, "Concha Espina, el refugio de la escritura”, El Diario, 12 Kasım 2016. (http://bit.ly/2BRNud1)

Crespo de Lara, Pedro, "El monumento a Concha Espina en Loredo", El Diario, 12 Eylül 2007. (https://rb.gy/bibrkg)

Renacimiento, Concha Espina, De su vida de su obra literaria a través de la critica universal, Madrid, 1928.

Espina, Concha, Obras completas-Cilt I, Fax, Madrid, 1955.

Gallego Méndez, María Teresa, Mujer, falange y franquismo, Taurus, Madrid, 1983.

Gráfica Informaciones, Biografía literaria de Concha Espina, Madrid, 194-?.

Gonzalez-Allende, Iker, Lineas de Fuego: Genero y Nacion En La Narrativa Espanola Durante La Guerra Civil (1936-1939), Biblioteca Nueva, Madrid, 1969.

Maza, Josefina de la, Vida de mi madre Concha Espina, Editorial Magisterio Español, Madrid, 1969. 
Molas i Ribalta, Pere, "Las primeras damas de la orden de María Luisa”, Trocadero, S.12-13, 2001. (https://revistas.uca.es/index.php/trocadero/article/download/755/621/2471)

Moran, Berna, Edebiyat Kuramları ve Eleştiri, İletişim Yayınları, 2007.

Rojas Auda, Elizabeth, Visión y ceguera de Concha Espina: su obra comprometida, Editorial Pliegos, Madrid, 1998.

Weisstein, Ulrich, “Expressionism: Style or Weltanschaung?”, Criticism, S.9, 1967.

Wilson, Katharina M., An Encyclopedia of Continental Women Writers, New York, Garland Publishing, 1991.

Ugarte, Michael. "The Fascist Narrative of Concha Espina", Arizona Journal of Hispanic Cultural Studies, S.1, 1997.

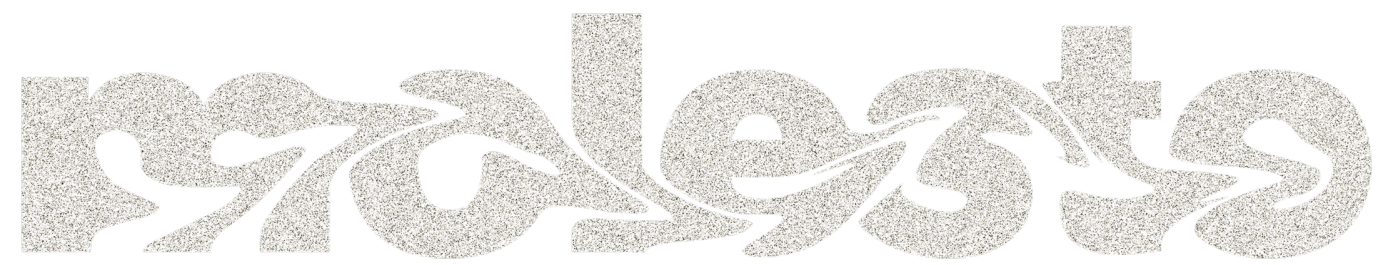

